\title{
Palm Oil Mill Efluent - Zeolite Mixture Improves Acid and Base Cations in Acid Sulfate Soil
}

\author{
Ida Nursanti \\ Faculty of Agriculture, Batanghari University, Jl. Slamet Riyadi, Jambi, Indonesia. \\ e-mail: idanursanti149@gmail.com
}

Received Agustus 21, 2019; Revised November 2, 2019; Accepted November 11, 2019

\begin{abstract}
Acid sulfate soil contains high acid cations. Palm oil mill effluent (POME) mixed with zeolite can increase $\mathrm{pH}$ of acid sulfate soil. Base cations ( $\mathrm{Ca}, \mathrm{K}$ and $\mathrm{Mg}$ ) on zeolite are exchangeable with $\mathrm{H}^{+}$and $\mathrm{Al}^{3+}$ ions in acid sulfate soil. The aim of this study was to investigate the effects of application of POME-zeolite mixture on acid cations of acid sulfate soil. The study was arranged in a Completely Randomized Design, with 9 treatments of POME applied on 10 $\mathrm{kg}$ of acid sulfate soil. Acid sulfate soil was put into $45 \mathrm{~cm} \mathrm{x} 40 \mathrm{~cm}$ polybag. POME plus zeolite powder (60 mesh, type clinoptilolite) was applied on soil by watering evenly and incubated for 4 weeks at room temperature. The results showed that the content of acid cations of exchangeable-Al and exchangeable-H decreased by $71.21 \%$ and $27.71 \%$, respectively after application of POME -zeolite. The application of POME without zeolite decreased the content of exchangeable-Al and exchangeable- $\mathrm{H}$ by $46.54 \%$ and $42.75 \%$, respectively. Aluminium saturation has decreased after POME-zeolite application from $42.68 \%$ (high) to $8.52 \%$ (very low). Base saturation increased after application of POME-zeolite application from $17.64 \%$ (very low) to $34.88 \%$ (low). Application of palm oil mill effluent-zeolite mixture decreased acid cations in acid sulfate soil. Base saturation correlates positively to $\mathrm{pH}$ and cation exchange capacity and negatively correlates to $\mathrm{Al}$ saturation. The main factors controlling the increase of $\mathrm{pH}$, base saturation and cation exchange capacity of acid sulfate soil after POME-zeolite application were the decrease of exchangeable-H, followed by exchangeable-Al and total-Fe.
\end{abstract}

Keywords: Acid cations, acid sulfate soil, base cations, pH, POME, zeolite

\begin{abstract}
ABSTRAK
Tanah sulfat masam memiliki tingkat kemasaman yang tinggi. Limbah Cair Pabrik Kelapa Sawit (LCPKS) dapat meningkatkan $\mathrm{pH}$ tanah dengan penambahan zeolit. Kation-kation basa $\mathrm{Ca}, \mathrm{K}$ dan $\mathrm{Mg}$ pada zeolit dipertukarkan dengan ion $\mathrm{H}^{+}$dan $\mathrm{Al}^{3+}$ pada tanah sulfat masam. Pelaksanaan penelitian di Desa Ulu Lagan, Tanjung Jabung Timur, Provinsi Jambi, menggunakan Rancangan Acak Kelompok dengan 9 perlakuan dan 3 kelompok. Faktor perlakuan terdiri dari A = LCPKS+zeolit 10\% (WPH 2 minggu) dosis $500 \mathrm{ml} \mathrm{polybag}^{-1}, \mathrm{~B}=\mathrm{LCPKS}+\mathrm{zeolit}$ 10\% (WPH $\left.2 \mathrm{minggu}\right)$ dosis $750 \mathrm{ml} \mathrm{polybag}^{-1}, \mathrm{C}=\mathrm{LCPKS}+$ zeolit $10 \%$ (WPH 2 minggu) dosis $1000 \mathrm{ml} \mathrm{polybag}^{-1}, \mathrm{D}=\mathrm{LCPKS}+$ zeolit $5 \%$ (WPH 2 minggu) dosis $500 \mathrm{ml} \mathrm{polybag}^{-1}, \mathrm{E}=\mathrm{LCPKS}$ zeolit $5 \%$ (WPH 2 minggu) dosis $750 \mathrm{ml} \mathrm{polybag}^{-1}, \mathrm{~F}=\mathrm{LCPKS}$ zeolit $5 \%$ (WPH 2 minggu) dosis $1000 \mathrm{ml} \mathrm{polybag}^{-1}$. G= LCPKS (WPH 4 minggu) dosis $500 \mathrm{ml}$, H=LCPKS (WPH 4 minggu) dosis $750 \mathrm{ml}$, I= LCPKS(WPH 4 minggu) dosis $1000 \mathrm{ml}$. Zeolit dan LCPKS mempengaruhi $\mathrm{pH}$ tanah dan $\mathrm{pH}$ tanah berkorelasi positif sangat nyata dengan KTK dan C-organik serta berkorelasi negatif dengan Al-dd dan Fe total. Kejenuhan basa berkorelasi positif dengan $\mathrm{pH}$ dan KTK serta berkorelasi negatif dengan kejenuhan Al, korelasi negatif terjadi antara kejenuhan Al dengan $\mathrm{pH}$, dan KTK . Faktor utama peningkatan $\mathrm{pH}$, kejenuhan basa dan KTK tanah sulfat masam potensial setelah perlakuan LCPKS+zeolit adalah penurunan $\mathrm{H}$-dd kemudian diikuti Al-dd dan Fe.
\end{abstract}

Kata Kunci: Kation asam, kation basa, pH, tanah sulfat masam, LCPKS, zeolit

\section{INTRODUCTION}

Palm oil mill effluent (POME) contains N, P, $\mathrm{K}, \mathrm{Ca}, \mathrm{Mg}$, and various types of microbes that benefit for plant nutrition and soil amendment. Palm oil mill effluent can be used as organic fertilizer with the addition of zeolite. Application of $10 \%$ zeolite and hydrolysis detection time (HDT) within 2 weeks on POME acidic pool and application of 5\% zeolite and HDT within 2 weeks on POME secondary anaerobic pool can produce better levels of $\mathrm{N}, \mathrm{P}$, 
$\mathrm{K}, \mathrm{Fe}, \mathrm{Al}, \mathrm{BOD}$ and $\mathrm{pH}$ according to waste standard quality. The addition of zeolite followed by HDT treatment on POME will result in better $\mathrm{N}, \mathrm{P}, \mathrm{K}, \mathrm{Al}$, $\mathrm{Fe}, \mathrm{BOD}$ and $\mathrm{pH}$ levels compared to zeolite treatment without HDT and HDT without zeolite treatment (Nursanti et al. 2013a).

Zeolite is negatively charged minerals, which can be neutralized by alkali metals, having pores filled with $\mathrm{K}, \mathrm{Na}, \mathrm{Ca}, \mathrm{Mg}$ and $\mathrm{H}_{2} \mathrm{O}$ molecules, allowing for the exchange of ions and the release of water back and forth. Besides being a cation exchanger, zeolite also serves as cation absorbent, such as $\mathrm{Pb}, \mathrm{Al}, \mathrm{Fe}, \mathrm{Mn}, \mathrm{Zn}$, and $\mathrm{Cu}$, so the zeolite can reduce heavy metal pollution in the environment (Oste et al. 2002; Wingenfelder et al. 2005).

Utilization of potential acid sulfate soils for agriculture is confronted with less supportive soil chemical properties due to low $\mathrm{pH}$, high levels of $\mathrm{Al}, \mathrm{Fe}, \mathrm{Mn}$ and $\mathrm{SO}^{2-}$, high salt content, and deficiency of $\mathrm{P}, \mathrm{Cu}, \mathrm{Zn}$, and $\mathrm{B}$. These problems arise due to the presence of pyrite layer. This pyrite layer should be in the lower layers because if it is oxidized it can cause soil acidity and high levels of nutrient toxicity to plants (Fahmi and Hanudin 2008).

The increase of $\mathrm{pH}$ of acid sulfate soil is affected by zeolite. The basic cations present in zeolite such as $\mathrm{Ca}, \mathrm{K}$ and $\mathrm{Mg}$ are interchangeable with $\mathrm{H}^{+}$and $\mathrm{Al}^{3+}$ ions. Zeolite can support soil $\mathrm{pH}$, neutralize acid soils, adsorb $\mathrm{Al}$ and $\mathrm{Fe}$ causing soil acidity and release basic cations such as $\mathrm{Ca}, \mathrm{Mg}$ and $\mathrm{K}$ (Endro 2008). $\mathrm{Ca}^{2+}, \mathrm{Mg}^{2+}, \mathrm{K}^{+}$cations in soil will be hydrolysed and produced hydroxide compounds and react with soluble $\mathrm{Al}$ ions in the soil solution to produce insoluble $\mathrm{Al}(\mathrm{OH})_{3}$ (Ano and Ubachi 2007).

The application of $1000 \mathrm{~mL}$ POME plus $10 \%$ zeolite can increase the $\mathrm{pH}$ of acid sulfate soil from 4.10 to 7.03 . The application of $500 \mathrm{~mL}$ POME plus $5 \%$ zeolite resulted soil $\mathrm{pH}$ of 4.27 . The dose of $1000 \mathrm{~mL}$ POME plus $10 \%$ zeolite can increase soil organic-C from $1.76 \%$ to $3.12 \%$. The soil $\mathrm{P}_{2} \mathrm{O}_{5}$ content increased from the low criteria $(14.30 \mathrm{mg}$ $\left.\mathrm{kg}^{-1}\right)$ to high criteria $\left(36.11 \mathrm{mg} \mathrm{kg}^{-1}\right)$ after application of $1000 \mathrm{~mL}$ POME plus $10 \%$ zeolite. Base saturation increased from $22.06 \%$ to $34.88 \%$ after application of $750 \mathrm{~mL}$ POME plus $10 \%$ zeolite. The content of exchangeable-Al and - $\mathrm{H}$ acid cations decreased about $43.69 \%$ and $16.67 \%$, respectively after application of $1000 \mathrm{~mL}$ POME plus $10 \%$ zeolite, compared to that after treatment with $500 \mathrm{~mL}$ POME plus $5 \%$ zeolite. Aluminum saturation decreased from $22.16 \%$ to $8.52 \%$ after treatment with $1000 \mathrm{~mL}$ POME plus $10 \%$ zeolite compared to that after treatment with $500 \mathrm{~mL}$ POME plus $5 \%$ zeolite (Nursanti et al. 2013b).
The objectives of this study was to determine the correlation between soil $\mathrm{pH}$ and cation exchange capacity, base saturation, Al, Fe and organic-C, and to find out the main factors that play roles in increasing $\mathrm{pH}$, cation exchange capacity, and base saturation of acid sulfate soil treated with POMEzeolite mixture.

\section{MATERIALS AND METHODS}

\section{Research Design}

Acid sulfate soil in Lagan Ulu Village, Geragai District, Jabung Timur Regency, Jambi Province is located at $1^{\circ} 11^{\prime} 58.66^{\prime \prime} \mathrm{N}$ and $103^{\circ} 44^{\prime} 6.19^{\prime \prime} \mathrm{E}$. The study was conducted in 3 months. The study was arranged in a Completely Randomized Design with 9 treatments, namely A $=500 \mathrm{~mL}$ POME $+10 \%$ zeolite; $\mathrm{B}=750 \mathrm{~mL}$ POME $+10 \%$ zeolite; $\mathrm{C}=1000 \mathrm{~mL}$ POME + $10 \%$ zeolite; $\mathrm{D}=500 \mathrm{~mL}$ POME $+5 \%$ zeolite; $\mathrm{E}$ $=750 \mathrm{~mL}$ POME $+5 \%$ zeolite; $\mathrm{F}=1000 \mathrm{~mL}$ POME $+5 \%$ zeolite; $\mathrm{G}=500 \mathrm{~mL}$ POME; $\mathrm{H}=$ $750 \mathrm{~mL}$ POME; and $\mathrm{I}=1000 \mathrm{~mL}$ POME. Acid sulfate soil was taken at a depth of $0-30 \mathrm{~cm}$ and put into $45 \mathrm{~cm} \times 40 \mathrm{~cm}$ polybag. Application of POME plus zeolite powder (60 mesh, type clinoptilolite) on $10 \mathrm{~kg}$ of acid sulfate soil was conducted by watering evenly and the soil was incubated for 4 weeks at room temperature.

\section{Soil Analysis}

Soil chemical analysis including available-P (Bray-1), total-Fe (diethylene triamine penta acetic acid/DTPA extraction), total-N (Kjedahl), exchangeable- $\mathrm{K}\left(\mathrm{NH}_{4} \mathrm{OAc} \mathrm{pH}\right.$ 7), exchangeable$\mathrm{Ca}\left(\mathrm{NH}_{4} \mathrm{OAc} \mathrm{pH} 7\right)$, exchangeable- $\mathrm{Mg}(\mathrm{NH} 4 \mathrm{OAc}$ $\mathrm{pH}$ 7), organic-C (Walkey and Black), CEC $\left(\mathrm{NH}_{4} \mathrm{OAc} \mathrm{pH} 7\right), \mathrm{S}$ content (spectrophotometry), $\mathrm{pH} \mathrm{H}_{2} \mathrm{O}(1: 1)$ and $\mathrm{pH} \mathrm{KCl} \mathrm{(1:1)} \mathrm{(electrometric}$ method), exhangeable-Al ( $\mathrm{KCl}$ extraction), and exhangeable- $\mathrm{H}(\mathrm{KCl}$ extraction) was conducted.

\section{Soil Characteristics}

Soil layer observation at 20,30,40,50, and 60 $\mathrm{cm}$ depths showed that the layers of acid sulfate soil are massive, unstructured, pale gray to dark gray, with groundwater level at $100 \mathrm{~cm}$. Pyrite was observed at 30, 40, 50 and $60 \mathrm{~cm}$ depths with the contents of $0.08,0.12,0.13,0.15$ and $0.21 \%$, respectively. The results of soil analysis (Table 1) showed that the soil was classified as clay texture, low cation exchange capacity, very acidic, low available-P and low total-N content. 
Table 1. Characteristics of acid sulfate soil before treatment.

\begin{tabular}{|c|c|c|}
\hline Parameter & value & Criteria *) \\
\hline $\mathrm{pH} \mathrm{H}_{2} \mathrm{O}(1: 1)$ & 4.10 & very acidic \\
\hline pH KCl (1:1) & 3.40 & \\
\hline $\mathrm{EC}\left(\mathrm{mS} \mathrm{cm}^{-1}\right)$ & 0.18 & no salt \\
\hline Organic C (\%) & 1.76 & low \\
\hline Total N (\%) & 0.18 & low \\
\hline $\mathrm{C} / \mathrm{N}$ ratio & 9.78 & low \\
\hline Available-P $\left(\mathrm{mg} \mathrm{kg}^{-1}\right)$ & 14.30 & low \\
\hline $\mathrm{K}$-total $\left(\mathrm{mg} \mathrm{kg}^{-1}\right)$ & 43 & high \\
\hline $\operatorname{Exc}-\mathrm{Ca}\left(\mathrm{cmol}_{(+)} \mathrm{kg}^{-1}\right)$ & 1.08 & very low \\
\hline $\operatorname{Exc}-\mathrm{Mg}\left(\mathrm{cmol}_{(+)} \mathrm{kg}^{-1}\right)$ & 1.30 & moderate \\
\hline Exc-Na $\left(\mathrm{cmol}_{(+)} \mathrm{kg}^{-1}\right)$ & 0.98 & high \\
\hline Exc-K $\left(\mathrm{cmol}_{(+)} \mathrm{kg}^{-1}\right)$ & 0.47 & moderate \\
\hline Exc-H $\left(\mathrm{cmol}_{(+)} \mathrm{kg}^{-1}\right)$ & 1.38 & low \\
\hline $\mathrm{CEC}\left(\mathrm{cmol}_{(+)} \mathrm{kg}^{-1}\right)$ & 15.24 & low \\
\hline Al-exc $\left(\mathrm{cmol}_{(+)} \mathrm{kg}^{-1}\right)$ & 4.34 & \\
\hline Al Saturation (\%) & 45.45 & high \\
\hline Base Saturation (\%) & 25.13 & low \\
\hline $\mathrm{Fe}(\%)$ & 1.61 & \\
\hline S (\%) & 0.15 & \\
\hline
\end{tabular}

Note: *) based on the criteria proposed by Pusat Penelitian Tanah (1995).

\section{Palm Oil Mill Effluent Characteristics}

The POME used was secondary anerobic pool POME with $\mathrm{pH}$ of 6.82 , total-N content of $0.18 \%$, total-P of $0.07 \%$ and BOD of $3.01 \mathrm{~g} \mathrm{~L}^{-1}$.

\section{Data Analysis}

The data were analyzed using the Analysis of Variance using Statistical Analysis System Version 17. The Duncan Multiple Range Test (DMRT) at $5 \%$ significance level was performed to compare the mean of each treatment. Furthermore, the correlation test was performed to determine the level of relationship between independent and dependent variables.

\section{RESULTS AND DISCUSSION}

The results of correlation analysis of several soil chemical properties after POME-zeolite application (Table 2) showed that the soil $\mathrm{pH}$ is positively correlated to $\mathrm{CEC}$ and organic-C and negatively correlated to exchangeable- $\mathrm{Al}$ and $-\mathrm{Fe}$ levels. The increase of $\mathrm{pH}$ will be followed by the increase of CEC and organic- $\mathrm{C}$ and the decrease of exchangeable-Al and Fe levels. The increase of CEC will be followed by the decrease of exchangeable-Al and $\mathrm{Fe}$ levels.

The application of POME-zeolite resulted in a higher base cation content in acid sulfate soil compared to that POME without zeolite application (Table 3). The highest content of base cations was measured in the treatment of $1000 \mathrm{~mL}$ POME $+10 \%$ zeolite with the level of moderate to very high, while the lowest content of base cations was measured in $500 \mathrm{~mL}$ POME without zeolite with very low to moderate level of base cations. The soil base saturation increased after $\mathrm{POME}+$ zeolite application (34.88\%, low) compared to that in POME (without zeolite) application ( $17.64 \%$, very low).

Table 2. Correlations of organic-C, $\mathrm{CEC}, \mathrm{pH}$, exchangeable-Al and -Fe due to the application of POME-zeolite on acid sulfate soil.

\begin{tabular}{ccccc}
\hline & \multicolumn{4}{c}{ Correlation Coefficient Value } \\
\cline { 2 - 5 } Variable & Org-C & CEC & Fe & $\mathrm{Al}$ \\
\hline $\mathrm{pH}$ & $+0.80^{* *}$ & $+0.70^{* *}$ & $-0.70^{* *}$ & $-0.73^{* *}$ \\
Org-C & - & $+0.54^{* *}$ & $-0.67^{* *}$ & $-0.68^{* *}$ \\
$\mathrm{CE}$ & - & - & $-0.74^{* *}$ & $-0.61^{* *}$ \\
\hline
\end{tabular}

Note: * $*$ very significant at $1 \%$ significance level. 
Table 3. The amounts of exchangeable bases, base saturation (BS) and Al saturation of acid sulfate soil due to the application of POME-zeolite and POME without zeolite.

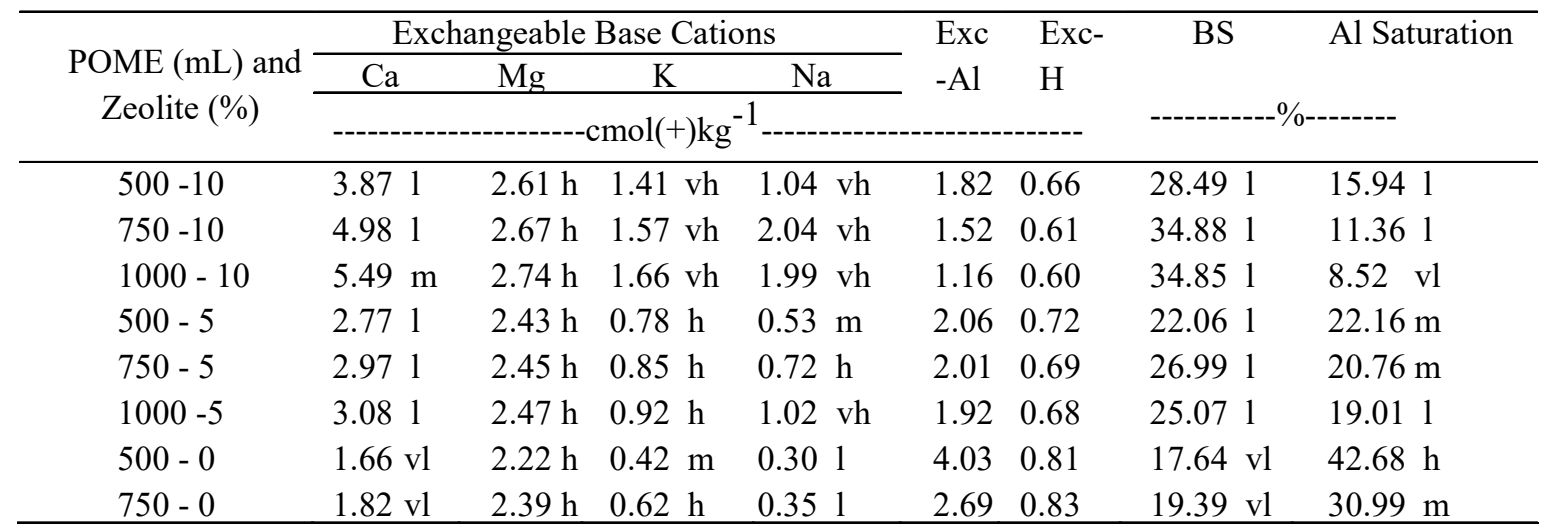

Note: The letters in each column indicate the criteria for assessing the nature of the soil (LPT, 1983): vl= very low, $\mathrm{l}=$ low, $\mathrm{m}=$ moderate, $\mathrm{h}=$ high, $\mathrm{vh}=$ very high.

The results of correlation analysis indicated that the increase of organic-C is followed by the increase of $\mathrm{pH}$ and the decrease of exchangeable-Al. POME is a colloidal suspension containing dissolved organic materials and high solids thereby when applied to soil with low organic matter content, the organic matter content of the soil will increase with increasing dose of applied POME (Rashid et al. 2009).

Correlation analysis showed that the increase of organic-C is followed by the decrease of exchangeable-Al and -Fe (Table 2). The decrease of exchangeable-Al and -Fe is due to the role of dissolved organic materials in POME in the form of amino acids that can bind $\mathrm{A} 1$ and $\mathrm{Fe}$ cations to form insoluble Al-organic complex. Baharuexcin et al. (2009) showed that organic acids inhibit the liberation of $\mathrm{A} 1$ and $\mathrm{Fe}$ from the soil colloidal surfaces through the formation of stable Al-organic and $\mathrm{Fe}$-organic complexes. The hydrolysis of $\mathrm{Al}$ and $\mathrm{Fe}$ ions can increase the concentration of $\mathrm{H}^{+}$ions in the soil to decrease soil $\mathrm{pH}$. The formation of stable Al-organic and $\mathrm{Fe}$-organic complexes by dissolved organic acids present in POME causes the decrease of A1 and $\mathrm{Fe}$ ion activity, thus preventing the occurrence of hydrolysis of $\mathrm{Al}$ and $\mathrm{Fe}$ ions.

The content of exchangeable-Al and - $\mathrm{H}$ cations decreased $71.21 \%$ and $27.71 \%$, respectively after application of POME plus zeolite compared to that in the treatment of POME without zeolite. The application of non-zeolite POME can decrease the content of exchangeable-Al and $-\mathrm{H}$ cations by $46.54 \%$ and $42.75 \%$, respectively compared to the initial $\mathrm{Al}$ and $\mathrm{H}$ cation levels prior to the experiment. Aluminum saturation decreased to $8.52 \%$ (very low) after POME+zeolite treatment compared to that in POME without zeolite, i.e. $42.68 \%$ (high) (Table 3).

Multiple correlation analysis of CEC, Base Satutarion (BS), $\mathrm{pH}$ and $\mathrm{Al}$ saturation due to the effect of POME-zeolite application (Table 4) showed that the base saturation is positively correlated to $\mathrm{pH}$ and $\mathrm{CEC}$ and negatively correlated to $\mathrm{Al}$ saturation. Negative correlations between $\mathrm{Al}$ saturation and $\mathrm{pH}, \mathrm{CEC}$ and base saturation were observed. The increase of base saturation will be followed by the increase of $\mathrm{pH}$ and CEC and followed by the decrease of Al saturation. The increase of $\mathrm{Al}$ saturation will be followed by the decrease of $\mathrm{pH}, \mathrm{CEC}$ and base saturation.

An increase of $\mathrm{pH}$ due to zeolite application is possible because the base cations present in zeolite such as $\mathrm{Ca}, \mathrm{K}$ and $\mathrm{Mg}$ can be exchanged with $\mathrm{H}^{+}$ and $\mathrm{Al}^{3+}$ ions. Zeolite can improve soil $\mathrm{pH}$, acid soils can be neutralized because zeolite is neutral $(\mathrm{pH}$ 7.2) and can adsorb $\mathrm{Al}$ and $\mathrm{Fe}$ causing soil acidity and release base cations such as $\mathrm{Ca}, \mathrm{Mg}$ and $\mathrm{K}$. Kismolo et al. (2008) indicated that zeolite is a mineral that can neutralize soil $\mathrm{pH}$.

The level of relationship of exchangeable-Al, exchangeable- $\mathrm{H}$, and total-Fe with $\mathrm{pH}$ due to the application of POME-zeolite showed that the increase of acid sulfate soil $\mathrm{pH}$ due to the effect of exchangeable-H was greater than that of exchangeable-Al. The variance of exchangeable$\mathrm{H}$ is $58.01 \%$, exchangeable- $\mathrm{Al}$ is $33.41 \%$ and $\mathrm{Fe}$ is $8.57 \%$. Thus the main factor controlling the increase of $\mathrm{pH}$ of acid sulfate soil is exchangeable- $\mathrm{H}$ then followed by exchangeable-Al and Fe. The lower the exchangeable-Al, exchangeable- $\mathrm{H}$ and $\mathrm{Fe}$, the higher the soil $\mathrm{pH}$ is. The regression equation is presented below: 
Table 4. Correlations of CEC, Base Satutarion (BS), $\mathrm{pH}$, and Al saturation due to the application of POME-zeolite on acid sulfate soil.

\begin{tabular}{lccc}
\hline \multirow{2}{*}{ Variable } & \multicolumn{3}{c}{ Correlation Coefficient Value } \\
\cline { 2 - 4 } & $\mathrm{pH}$ & $\mathrm{CEC}$ & $\mathrm{BS}$ \\
\hline BS & $+0.79^{* *}$ & $+0.49^{* *}$ & - \\
Al Saturation & $-0.78^{* *}$ & $-0.68^{* *}$ & $-0.86^{* *}$ \\
\hline
\end{tabular}

Notes: $* *$ : very significant at $1 \%$ significance level.

$$
\begin{gathered}
\mathrm{Y}=-0.319 \times 1+0.927 \times 2-10.38 \times 3+12.423 \\
\mathrm{R}^{2}=0.97, \mathrm{Y}=\mathrm{pH}, \mathrm{x} 1=\text { exc-Al, } \mathrm{x} 2=\text { total-Fe, } \mathrm{x} 3=\text { exc-H }
\end{gathered}
$$

Notohadikusumo and Noor (2003) described that agronomic constraints for agricultural crops cultivated on acid sulfate soils, among others, is the direct effect of acidity due to the increase of solubility and toxicity of $\mathrm{Al}, \mathrm{Mn}$ and $\mathrm{H}^{+}$; and phosphate deficiency due to Al-P precipitation. Muzar (2008) showed that POME application can increase $\mathrm{pH}$ of acid soil from $\mathrm{pH} 4.53$ to 5.56 .

The association of exchangeable-Al, exchangeable- $\mathrm{H}$, and total-Fe with $\mathrm{pH}$ due to the application of POME without zeolite showed that the increase of acid sulfate soil $\mathrm{pH}$ due to the effect of exchangeable-Al was greater than that of exchangeable- $\mathrm{H}$ and total-Fe. The variance of exchangeable- $\mathrm{Al}$ is $53.84 \%$, exchangeable- $\mathrm{H}$ is $40.96 \%$ and total-Fe is $5.20 \%$. The regression equation is as follows:

$$
\begin{gathered}
\mathrm{Y}=-12.672 \times 1+2.540 \times 2-0.251 \times 3+12.00 \\
\mathrm{R}^{2}=0.94, \mathrm{Y}=\mathrm{pH}, \mathrm{x} 1=\text { exc-Al, } \mathrm{x} 2=\text { total-Fe, } \mathrm{x} 3=\text { exc-H }
\end{gathered}
$$

The increase of nutrient contents, such as total$\mathrm{N}$, available- $\mathrm{P}$, and exchangeable base cations $(\mathrm{Ca}$, $\mathrm{Mg}$, and $\mathrm{Na}$ ) are derived from mineralization of POME that releases these elements into the soil. In addition, the nutrient content is derived from POME decomposition and elements adsorbed by zeolite. Vaulina (2002) indicated that if the $\mathrm{N}$ content in the soil solution is less, then the $\mathrm{N}$ adsorbed on the zeolite will be released slowly. Palm oil mill effluent contains dissolved organic compounds that may play a role in increasing solubility of $\mathrm{P}$ present in acidic soils such as A1-P and Fe-P. The results of Ermadani et al. (2007) showed that application of organic acids (humic acids, oxalate and citrate) could increase available-P and total-P in soil.

Correlation analysis showed that an increase of organic-C content, total-N, available-P and base saturation will be followed by an increase of CEC and a decrease of $\mathrm{Al}$ saturation (Table 2 and 4). Wolf and Snyder (2003) indicated that the application of organic matter can increase the cation exchange capacity, soil $\mathrm{pH}$ and contribute a number of macro and micro nutrients through the process of mineralization. It is also explained that the function of organic matter in improving soil chemical fertility is also due to the decrease of nutrient losses by leaching due to the ion-binding by organic matter and immobilization of N, P and S and solubility of nutrients, especially phosphates and minerals by organic acids. The soil applied with POME-zeolite has a larger CEC compared to that applied with POME without zeolite, although both CEC are in the same criteria (Table 3).

This result is possible because the zeolite has a high CEC which is about $154.17 \mathrm{cmol}(+) \mathrm{kg}^{-1}$. Li et al. (2003) showed that the exchange of cations in zeolite is essentially a function of the degree of silica substitution by aluminum in the structure of zeolite crystals. The more the amount of aluminum replaces the silica position, the more the negative charge is generated, so the CEC of zeolite will be higher. Acid sulfate soils have variable charges, if the $\mathrm{pH}$ rises above neutral it will produce a negative charge. Negative charges are generated by the high incidence of $\mathrm{OH}^{-}$ions in the colloidal surfaces. Negative charges on the colloidal surfaces are able to adsorb the cations. Example of reaction is as follows:

$$
\mathrm{Al}-\mathrm{OH}+\mathrm{OH}^{-} \rightarrow \mathrm{Al}-\mathrm{O}^{-}+\mathrm{H}_{2} \mathrm{O}
$$

The level of relationship of exchangeable-Al, exchangeable-H, and total-Fe with CEC due to the application of POME-zeolite showed that the increase of CEC of acid sulfate soil due to the effect of exchangeable-H was greater than that of exchangeable-Al and total-Fe. The regression equation is generated:

$$
\begin{gathered}
\mathrm{Y}=21.48 \times 1-2.027 \times 2-2.491 \times 3+23.176 \\
\mathrm{R}^{2}=0.92, \mathrm{Y}=\mathrm{pH}, \mathrm{x} 1=\text { exc-Al, } \mathrm{x} 2=\text { total-Fe, } \mathrm{x} 3=\text { exc-H }
\end{gathered}
$$

Zeolite is a catalyst material that has the ability to improve the decomposition process of large 
molecular weight organic compounds (polymers) into simple organic compounds (monomers), which is supported by the nature of the zeolite electrostatic field and the role of pore space structure in zeolite. In addition, zeolite is the absorbing agent and $\mathrm{pH}$ neutralizer, which easily performs ion exchange (Ersoy and Celik 2003).

The adsorption process of ions that can cause soil acidity $\left(\mathrm{Al}^{3+}, \mathrm{Fe}^{3+}\right.$ and $\left.\mathrm{H}^{+}\right)$by zeolite occurs because there is an attraction between the ions that have a low electronegativity difference (Van Der Waals Style) and supported by the presence of cavities inside the zeolite which acts as a trap.

Level of relationship between exchangeable$\mathrm{Al}$, exchangeable- $\mathrm{H}$ and total-Fe with $\mathrm{CEC}$ due to the application of POME without zeolite shows that the decrease of CEC of acid sulfate soil due to the effect of exchangeable-H was greater than that of exchangeable-Al and total-Fe. The regression equation is presented as follows:

$$
\begin{gathered}
\mathrm{Y}=-0.156 \times 1+1.309 \times 2-18.468 \times 3+39.717 \\
\mathrm{R}^{2}=0.82, \mathrm{Y}=\mathrm{pH}, \mathrm{x} 1=\text { exc-A1, } \mathrm{x} 2=\text { total-Fe, } \mathrm{x} 3=\text { exc- } \mathrm{H}
\end{gathered}
$$

POME and zeolite are negatively charged. Application of POME and zeolite to soil means donating the negative charges to the soil, the higher the negative charge the higher the CEC will be, because the increase of the number of cations that are exchangeable. Furthermore, Fungaro and Graciano (2007) indicated that zeolite have open skeletons formed from primary builder units that further form secondary builder units. The morphology and structure of zeolite crystals consist of cavities that are connected in all directions that cause the surface of the zeolite to expand. There was a negative correlation between Al saturation with $\mathrm{pH}, \mathrm{CEC}$ and base saturation. The increase in base saturation will be followed by the increase in $\mathrm{pH}$ and $\mathrm{CEC}$ and followed by the decrease in $\mathrm{Al}$ saturation. The increase of $\mathrm{Al}$ saturation will be followed by the decrease of $\mathrm{pH}, \mathrm{CEC}$ and base saturation.

The increase of exchangeable base cations $(\mathrm{Ca}, \mathrm{Mg}$, and $\mathrm{Na})$ is derived from the mineralization of POME that releases these elements into the soil. In addition, the nutrients are derived from POME decomposition and elements adsorbed by zeolite. Wolf and Snyder (2003) and Budianta et al. (2020) indicated that the application of organic matter can increase the cation exchange capacity, soil $\mathrm{pH}$ and contribute a number of macro and micro nutrients through the process of mineralization.
The level of relationship between exchangeable-Al, exchangeable-H and total-Fe with base saturation due to the application of POMEzeolite showed that the increase of base saturation of acid sulfate soil due to the effect of exchangeable$\mathrm{H}$ was greater than that of exchangeable- $\mathrm{Al}$ and total-Fe. The regression equation is as follows:

$$
\begin{gathered}
\mathrm{Y}=-3.150 \times 1+13.048 \times 2-80.67 \times 3+80.354 \\
\mathrm{R}^{2}=0.89, \mathrm{Y}=\mathrm{pH}, \mathrm{x} 1=\text { exc-Al, } \mathrm{x} 2=\text { total-Fe, } \mathrm{x} 3=\text { exc-H }
\end{gathered}
$$

The level of relationship between exchangeable-Al, exchangeable- $\mathrm{H}$, and total-Fe with base saturation due to the application of POME without zeolite showed that the increase of base saturation of acid sulfate soil due to the effect of exchangeable-H was greater than that of exchangeable-Al and total-Fe. The regression equation is as follows:

$$
\begin{gathered}
\mathrm{Y}=-0.766 \mathrm{x} 1+1.237 \times 2-1.382 \times 3+23.22 \\
\mathrm{R}^{2}=0.97, \mathrm{Y}=\mathrm{pH}, \mathrm{x} 1=\mathrm{Al}-\mathrm{exc}, \mathrm{x} 2=\mathrm{Fe}, \mathrm{x} 3=\mathrm{H}-\mathrm{exc}
\end{gathered}
$$

\section{CONCLUSIONS}

The $\mathrm{pH}$ of acid sulfate soil applied with POME plus zeolite will increase, followed by the increase of $\mathrm{CEC}$ and organic-C content and the decrease of exchangeable-Al and total-Fe levels. The soil base saturation is positively correlated with $\mathrm{pH}$ and CEC and negatively correlated with $\mathrm{Al}$ saturation. There were negative correlations between $\mathrm{Al}$ saturation and $\mathrm{pH}, \mathrm{CEC}$ and base saturation. The $\mathrm{pH}$ of acid sulfate soil increases due to the effect of decreasing exchangeable-Al and total-Fe levels. The lower the exchangeable-Al and total-Fe in the soil, the soil $\mathrm{pH}$ will increase. The main factors influencing the increase of $\mathrm{pH}, \mathrm{CEC}$ and base saturation of acid sulfate soil applied with POME plus zeolite were exchangeable- $\mathrm{H}$, followed by exchangeable- $\mathrm{Al}$ and total-Fe.

\section{ACKNOWLEDGEMENTS}

The authors would like to thank Universitas Batanghari, Jambi for providing the facilities for this research.

\section{REFERENCES}

Ano AO and CI Ubochi. 2007. Neutralization of soil acidity by animal manures: mechanism of reaction. Afr $J$ Biotechnol 6: 364-368. 
Baharuexcin AS, M Wakisaka, Y Shirai, AS Abd, NA Rahman and MA Hassan. 2009. Co-composting of empty fruit bunches and partially treated palm oil mill effluents in pilot scale. Int J Agric Res: 6978.

Budianta D, AYA Wiralaga and W Lestari. 2010. Changes in some soil chemical properties of ultisol applied by mulch from empty fruit bunches in an oil palm plantation. J Trop Soils 15: 111-118.

Ermadani and AR Arsyad. 2007. Perbaikan beberapa sifat kimia tanah mineral masam dengan pemanfaatan limbah cair pabrik kelapa sawit. J Lembaga Penelitian Universitas Jambi Seri Science 9: 99105. (in Indonesian).

Ersoy B and MS Celik. 2003. Effect of hydrocarbon chain length on adsorption of cationic surfactants onto clinoptilolite. Clay Clay Miner 51: 172-180.

Fungaro DA and JEA Graciano. 2007. Adsorption of zinc ions from water using zeolite/iron oxide composites. Adsorpt Sci Technol 25: 729-740. doi: 10.1260/ 026361707785284185

Fahmi A and E Hanudin. 2008. Pengaruh kondisi redoks terhadap stabilitas kompleks organik-besi pada tanah sulfat masam. J Ilmu Tanah and Lingkungan 8: 49-55. (in Indonesian).

Kismolo E, Nurimaniwathy and T Suyatno. 2008. Optimasi pemanfaatan zeolit alam dari Gunung Kidul untuk reduksi kadar cesium dalam limbah radioaktif cair. Prosiding Seminar Nasional Penelitian and Pengelolaan Perangkat Nuklir. Pusat Penelitian dan Pengembangan Teknologi Maju Yogyakarta, pp. 390-395. (in Indonesian).

Li S, VA Tuan, RD Noble and JL Falconer. 2003. MTBE adsorption on all-silica $\beta$ zeolite. Environ Sci Technol 37: 4007-4010.

Muzar A. 2008. Aplikasi limbah cair pabrik kelapa sawit terhadap tanah ultisol and pengaruhnya pada tanaman kedelai. J Agrivigor 8: 24-32.
Nursanti I, D Budianto, A Napoleon and Y Parto. 2013a. Zeolite utilization as a catalyst and nutrient absorbent in an organic fertilizer processing derived from palm oil mill effluent as a raw material. J Trop Soils 18: 177-184.

Nursanti I, D Budianta, A Napoleon and Y Parto. 2013b. Perbaikan kesuburan tanah sulfat masam potensial melalui pemberian limbah cair pabrik kelapa sawit and zeolit berbagai dosis. In: Herlinda S, B Lakitan, Sobir, Koesnandar, Suwandi, Puspitahati, MI Syafutri, D Meidalima (eds). Prosiding Seminar Nasional Lahan Suboptimal. Palembang, Pusat Unggulan Riset Pengembangan Lahan Suboptimal (PUR-PLSO) Universitas Sriwijaya, pp. 297-305. (in Indonesian).

Notohadikusumo T, A Maas and M Noor. 2003. Pengaruh pelindian and perbaikan aerasi terhadap sifat kimia tanah sulfat masam Kalimantan. J Ilmu Tanah dan Lingkungan 4: 1-14. (in Indonesian).

Oste LA, TM Lexmond and V Riemsdijk. 2002. Metal immobilization in soils using synthetic zeolite. $J$ Environ Qual 31: 813-821.

Rashid SS, Z Alam, M Ismail, A Karim and MH Salleh. 2009. Management of palm oil mill effluent through production of cellulases by filamentous fungi. World J Microbiol Biotechnol 25: 2219-2226. (in Indonesian).

Vaulina E. 2002. Potensi zeolit alam sebagai absorban logam-logam berat pada limbah perairan. Majalah Ilmiah Universitas Jenderal soedirman. Purwokerto 2: 1-8. (in Indonesian).

Wingenfelder U, C Hansen, G Furrer and R Schulin. 2005. Removal of heavy metals from mine waters by natural zeolites. Environ Sci Technol 39: 4606-4613

Wolf B and GH Snyder. 2003. Sustainable Soils the Place Organic Matter in Sustainable Soils and their Productivity. Food Products Press. An Imprint of The Haworth Press, Inc. NewYork-London-Oxford. 